\title{
Brief Incident Report: Lessons Learned of Tehran-Zahedan Train Derail, Iran, 2019
}

\author{
Mahmoudreza Peyravi $^{1}$ (D), Milad Ahmadi Marzaleh ${ }^{1^{*}}$ (D) \\ 1. Department of Health in Disasters and Emergencies, School of Management and Medical Informatics, Shiraz University of Medical Sciences, \\ Shiraz, Iran.
}

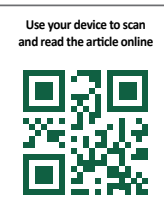

ctition Peyravi MR, Ahmadi Marzaleh M. Lessons Learned of Tehran-Zahedan Train Derail, Iran, 2019. Health in Emergencies and Disasters Quarterly. 2021; 6(4):251-254. http://dx.doi.org/10.32598/hdq.6.4.190.2

http://dx.doi.org/10.32598/hdq.6.4.190.2

Article info:

Received: 19 Dec 2020

Accepted: 02 March 2021

Available Online: 01 Jul 2021

\section{Keywords:}

Disaster, Response, Accident, Error, Coordination

\section{ABSTRACT}

Background: There has been a significant increase in the number of train crashes worldwide, mainly due to the extension of the rail network and the use of the most sophisticated and cutting-edge technology.

Incident Report: The Tehran-Zahedan train had 260 passengers on board and left for Tehran City at 14:50 local time on Wednesday, September 25, 2019. The accident happened at 16:20 local time at $100 \mathrm{~km}$ distance from Zahedan City.

Results: Five train cars derailed $2 \mathrm{~km}$ from Shorou Station, where four people died, and 157 were injured. According to the investigations, the accident occurred due to the unscrewing of some bolts and spring washers. There were 170-180 screws and spring washers removed along 50-60 m, which resulted in the creation of a dangerous point and derailment of the train. This study examined the challenges, strengths, and learned lessons of the incident.

Conclusion: Concerning standard and vast rail networks in Iran and the latest train crashes that mainly occurred just outside the cities, accessibility to the accident scene should be considered one of the most important physical vulnerability indexes. As a result, accessibility to special firefighting and rail rescue train car at some stations in crowded routes effectively decreases the consequences of such accidents.

\section{Introduction}

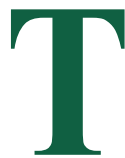

here has been a marked increase in the number of train crashes worldwide, mainly because of the extension of the rail network and the use of the most sophisticated and cutting-edge technology $[1,2]$.

\section{Brief Report of Accident}

Semnan and Neishabour rail disasters are two cases in point. On February 20, 2003, at 4:10 local time, 51 freight wagons (4 empty first wagons, 5 next gasoline wagons, 10 cotton wagons, 1 gasoline wagon, 9 sulfur wagons, 7 ammonium nitrate fertilizer wagons, 2 empty wagons, 8 sulfur wagons, and 5 empty end wagons) ran away with-

\section{"Corresponding Author:}

Milad Ahmadi Marzaleh, PhD.

Address: Department of Health in Disasters and Emergencies, School of Management and Medical Informatics, Shiraz University of Medical Sciences, Shiraz, Iran.

E-mail: miladahmadimarzaleh@yahoo.com 
out a driver. Because of the area's downward slope, the train left the sideline and entered the main route, $20 \mathrm{~km}$ from Abu Muslim Station (three stations before Neishabour Station), and passed Khayyam Station. The Neishabour train explosion occurred when the wagons without a locomotive inadvertently escaped from Abu Muslim Station and railed on the Mashhad route and after a distance collided by another freight train carrying sulfur chemical.

They crashed at Khayyam Station, a station before Neishabour, near the village of Dehno Hashemabad. Another accident was the train collision on the SemnanDamghan axis between two passenger trains near Haft Khan Station on this axis. In this incident, which took place at 7:22 local time on Friday, December 26, 2016, the Semnan-Mashhad train collided from behind with the Tabriz-Mashhad train, which was stopped on the same rail. Following the collision of two trains, four wagons derailed, and five wagons caught fire [3-5]. The last accident was related to the Tehran-Zahedan train with 260 passengers on board. It left for Tehran at 14:50 local time on Wednesday, September 25, 2019. The accident happened at 16:20 local time at $100 \mathrm{~km}$ from Zahedan. Five train cars derailed $2 \mathrm{~km}$ from Shorou Station, where four people died, and 157 were injured.

\section{Causes}

According to the investigations, the accident occurred because of unscrewing some bolts and spring washers. There were 170-180 screws and spring washers removed along 50-60 m, which resulted in the creation of a dangerous point and derailment of the train.

\section{Actions taken}

Various relief organizations, including the Red Crescent, the Ministry of Health, the Prehospital Emergency Department, the Fire Department, and the police, arrived at the scene on time and played a crucial role in managing the incident. Firefighters, Red Crescent, and emergency care forces were sent to the scene of the accident after receiving its report from local people. All injured people were taken to Zahedan hospitals using helicopters, buses, and ambulances.

\section{Challenges}

Relief forces arrived late at the scene mainly because of the mountainous region. There were some challenges and mismanaging the rail accident in the presence of the Red Crescent and emergency care forces at the accident scene. These problems consisted of no accident com- manding system when the accident happened, failure to consider safety standards, and keeping a safe distance from the accident scene by the relief workers.

\section{Strengths}

Emergency care, Red Crescent, firefighting, police forces, and road and railway organizations worked in good collaboration. Efforts of the Zahedan crisis management workgroups played a pivotal role in speeding up the rescue and relief processes. The accessibility to a helicopter not only assisted in taking the severely injured people to hospitals but also offered passengers, the Zahedan crisis management organization, and the Red Crescent Society good mental relaxation. The readiness of the Red Crescent flying personnel was praiseworthy. The capability of the pilot during the night flights was excellent. Local inhabitants near the accident scene reached there before the relief workers and took many injured people to Zahedan medical centers by their private vehicles. Their capacity was effectively used. The triage was done for the wounded people to speed up the registration process in therapeutic centers. Police and firefighters arrived at the scene on time.

\section{Lessons learned}

1. It is necessary to set up rapid response forces in all provinces because the mortality rate would decrease with the timely arrival of relief workers at the accident scene.

2. Modern and up-to-date rescue and relief facilities are required for train crashes.

3. Setting up a command system would assist relief workers towards better collaboration.

4. Observation and keeping regular control over urban and suburban rail networks may help prevent such accidents.

5. Risk assessment and detailed analysis of significant causes when such accidents occur will increasingly prevent the repetition of similar problems.

6. The presence of firefighting equipment and prehospital emergency personnel on all trains helps reduce damage and casualties [6].

7. Development of emergency locks on trains to prevent accidents and collisions with wagons [7] 


\section{Suggestions}

To prevent future incidents, It is proposed to take measures such as launching an accident control system on trains, electronic and continuous tracking of trains, establishing inherently safe methods, and creating parallel railway lines.

\section{Conclusion}

With regard to standard and vast rail networks in Iran and concerning the previous train crashes that mainly occurred just outside the cities, accessibility to the scene of the accident should be considered one of the most important physical vulnerability indexes. As a result, accessibility to special firefighting and rail rescue train car at some stations and in crowded routes is effective in decreasing the frequency of such accidents. Moreover, equipping trains with the cutting-edge technology of automatic control intelligent systems, effective management of human resources, and improving work processes (e.g. setting up a response system in all levels and close observation over the control system) should be taken into consideration as the learned experiences of the previous rail accidents. These measures could prevent the occurrence of similar accidents. Meanwhile, accurate identification of all influential factors in railway accidents plays a pivotal role in decreasing the dangerous and disastrous consequences of rail accidents.

\section{Ethical Considerations}

\section{Compliance with ethical guidelines}

There were no ethical considerations to be considered in this research.

\section{Funding}

This research did not receive any grant from funding agencies in the public, commercial, or non-profit sectors.

\section{Authors' contributions}

All authors equally contributed to preparing this article.

\section{Conflict of interest}

The authors declared no conflict of interest.

\section{Acknowledgments}

We greatly appreciate the administration and personnel of Iranian Red Crescent and Sistan and Baluchestan Red Crescent for their assistance in conducting this study.
The authors would like to thank Ms A. Keivanshekouh at the Research Improvement Center of Shiraz University of Medical Sciences for improving the English writing of the manuscript.

\section{References}

[1] Li Y-F, Mi J, Huang H-Z, Zhu S-P, Xiao N. Fault tree analysis of train rear-end collision accident considering common cause failure. Eksploatacja i Niezawodność. 2013; 15(4):403-8. http://yadda.icm.edu.pl/baztech/element/bwmeta1.element.baztech-c4cc08e2-5634-47ec-8cf4-67f00953ec93

[2] Collins JA, inventor; Collins Joseph A, assignee. Train derail emergency brake system. United States patent US 4,269,288. 1981 May 26. https:/ / patents.google.com/patent/ US4269288A/en

[3] Bargegol I, Najafi Moghaddam Gilani V, Abolfazlzadeh M. Statistical analysis of the railway accidents causes in Iran. International Journal of Engineering. 2017; 30(12):1822-30. [DOI:10.5829/ije.2017.30.12c.02]

[4] Koohi I. Accidents analysis of rail transportation industry in Iran. World Applied Sciences Journal. 2009; 7(3):358-65. https:// citeseerx.ist.psu.edu/viewdoc/download?doi=10.1 1.388.4604\&rep=rep1\&type $=$ pdf

[5] Jahangiri K, Ghodsi H, Khodadadizadeh A, Nezhad SY Pattern and nature of Neyshabur train explosion blast injuries. World Journal of Emergency Surgery. 2018; 13:3. [DOI:10.1186/s13017-018-0164-7] [PMID] [PMCID]

[6] Altmann EM, Trafton JG, Hambrick DZ. Momentary interruptions can derail the train of thought. Journal of Experimental Psychology: General. 2014; 143(1):215-26. [DOI:10.1037/ a0030986] [PMID]

[7] Haney C, Carr J, Reid J, inventors; GE Railcar Services Corp, assignee. Lock extension for train derail. United States patent US 7,735,783. 2010 Jun 15. https://patents.google.com/patent/US7735783 
This Page Intentionally Left Blank 